\title{
Instabilidade ântero-inferior traumática do ombro: Procedimento de Bankart em atletas não profissionais
}

\author{
Traumatic Antero-inferior instability of the shoulder: Bankart's procedure
} in nonprofessional athletes

\author{
Ubiratan Maia Rodrigues Vasconcelos ${ }^{1}$, Adriano Barros de Aguiar Leonardi², André Luiz Reis ${ }^{3}$, \\ Guaracy Carvalho Filho ${ }^{4}$, Alceu Gomes Chueire ${ }^{5}$
}

\section{RESUMO}

Foram avaliados vinte e um atletas não profissionais (vinte e um ombros) no período de Fevereiro de 1999 a Março de 2002 com idade media de 26,63 anos portadores de instabilidade antero-inferior traumática. Todos foram submetidos ao tratamento cirúrgico pela tecnica de Bankart com âncoras. O retensionamento capsuloligamentar foi realizado quando o sinal do sulco foi detectado ao exame físico ou durante o ato cirúrgico.

Segundo os critérios de Rowe et al. (20), obteve-se quinze resultados excelentes, três bons, dois regulares e um ruim. No pós-operatório, a média da rotações interna, utilizando o nível vertebral como parâmetro foi de T12, rotação externa de 27,19 graus e a abdução media de 166,90 graus, o teste do sulco foi positivo em um $(4,76 \%)$ paciente e houve recidiva em dois $(9,52 \%)$

O retorno às atividades esportivas deu-se em 16 atletas (76,19\%). Um dos principais fatores relacionados ao abandono e à reabilitação parcial foram o medo de recorrência da dor residual e instabilidade.

Descritores: Articulação do ombro; Cirurgia; Técnica de Bankart.

\section{INTRODUÇÃO}

Em virtude do pequeno contato das superfícies articulares entre a glenóide e a cabeça do úmero, a articulação glenoumeral é considerada a mais instável do corpo humano e responde por $45 \%$ das luxações do corpo humano, ocorrendo em torno de 1,5 a 2,0 \% da população em geral|(19).

O esporte, principalmente no hockey sobre o gelo , handebol, rugbi, rodeio e futebol, responde por $7 \%$ dos traumas do ombro $^{(9)}$. Quando o atleta cai, instintivamente levanta o braço em abdução e rotação externa, podendo desencadear a lesão. Outros mecanismos são o impacto violento com outro jogador, ou quando o braço é vigorosamente puxado para trás. Exemplos clássicos são o de um esquiador que pode cair com o braço abduzido, ou um caiaquista tendo seu braço puxado para

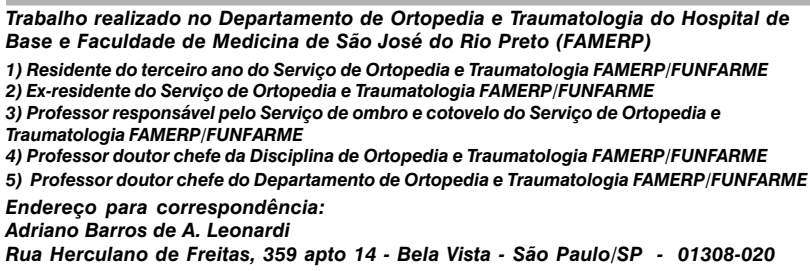

\section{SUMMARY}

Between February 1999 and March 2002, twenty-one nonprofessional nonprofessional athletes (21 shoulders, mean age of 26.63 years) with traumatic antero-inferior instability were evaluated. All of them underwent surgical treatment using the Bankart technique with anchors. The capsuloligament retensioning was performed after the sulcus sign was detected during physical examination or during the surgical act.

According to the criteria by Rowe et al(20), fifteen excellent results were obtained, three good, two regular, and one poor result. In the postoperative period, the mean internal rotation, using the vertebral level as a parameter, was T12. The external rotation was 27.19 degrees and the mean abduction was 166.90 degrees; the sulcus test was positive in one patient (4.76\%), while recurrence occurred in two patients (9.52\%).

Sixteen athletes returned to their sports activities (76.19\%). The main factors related to the abandonment and partial rehabilitation were the fear of residual pain recurrence, and instability.

Key words: Shoulder joint; Surgery; Bankart technique.

\section{INTRODUCTION}

Due to the small contact of joint surfaces between the glenoid and the humerus head, the glenohumeral joint is considered the most unstable joint in the entire human body, answering for $45 \%$ of the dislocations in humans and affecting between 1.5 and $2.0 \%$ of the general population ${ }^{(19)}$.

Sports, particularly ice hockey, handball, rugby, rodeo and football, are responsible for $7 \%$ of all shoulder traumas ${ }^{(9)}$. When an athlete falls, he or she will instinctively raise their arm in external abduction and rotation, which may trigger an injury. Other mechanisms include a violent impact with another player or in case the arm is vigorously pulled backwards. Among the classical examples are the skier who may fall with his arm abducted, or a kayak user whose arm is pulled backwards over the head while he struggles with turbulent waters ${ }^{(8,19)}$.

This study was performed in the Department of Orthopedics and Traumatology, Base Hospital and Faculty of Medicine of Sao Jose do Rio Preto, SP, Brazil (FAMERP)

1) Third-year internist of Orthopedics and Traumatology Service of FAMERP/FUNFARME 2) Ex-internist of Orthopedics and Traumatology Service of FAMERP/FUNFARME 3) Professor responsible for the Shoulder and Elbow Service of Orthopedics and Traumatology Service of FAMERP/FUNFARME

4) Head Professor Doctor of Orthopedics and Traumatology Discipline of FAMERP/FUNFARME 5) Head Professor Doctor of Orthopedics and Traumatology Department of FAMERP/FUNFARME Address: Adriano Barros de A. Leonardi

Rua Herculano de Freitas, 359 apto 14 - Sao Paulo, SP 01308-020 - Brazil 
trás por cima da cabeça enquanto faz força na água turbulenta ${ }^{(8,19)}$.

Durante o evento primário, quand o o ombro é submetido à abdução, rotação externa e extensão máximas, o manguito rotador torna-se incapaz de manter a cabeça umeral centrada na fossa glenoide não resistindo às forças externas que é então desviada anteriormente à glenóide. Na grande maioria das vezes, permanece inferior ao processo coracóide ${ }^{(19)}$. Lesões capsuloligamentares, quando presentes, dar-se-ão no ponto mais fraco (ponto de fadiga) localizado na cápsula inferior e labrum glenóideo, caracterizando-se, assim, a lesão de Bankart(7,16,24).

Embora haja grande dificuldade em se diferenciar episódios de luxação quanto à recorrência e instabilidade entre traumática e atraumática, especialmente em jovens atletas, fatores a serem considerados são o mecanismo clássico do trauma e a presença de hiperfrouxidão ligamentar generalizada ${ }^{(11)}$. Sabese que, a idade e a intensidade do trauma inicial são fatores intimamente relacionados. Segundo McLaughlin e McLellan ${ }^{(12)}$ a chance de recidiva ocorre em torno de $90 \%$ de atletas com menos de 20 anos , $60 \%$ entre 20 e 40 e $10 \%$ acima de 40 anos. Berg e Ellison ${ }^{(3)}$ acrescentam uma terceira categoria na qual, atribui-se aos de microtraumatismos repetitivos como fatores responsáveis a lesões cumulativas nos tecidos moles estabilizadores, gerando as chamadas lesões por overuse e, posteriormente, a instabilidade. É o caso de nadadores, ginastas, arremessadores e outros atletas que sobrecarregam o membro superior.

O chamado ombro de apreensão designa o temor de que 0 ombro vá luxar-se aos pequenos movimentos forçados ou involuntários. Pode ser mais limitador funcionalmente do que a própria instabilidade ${ }^{(19)}$.

A subluxação, comum em atletas portadores de luxação recidivante, tem como principal manifestação clinica a "Síndrome do braço morto" ou de "impacto secundário", nos quais a abdução e rotação externa levam a subluxação anterior, gerando dor aguda e perda momentânea da função do ombro com queda súbita do mesmo ${ }^{(8)}$.

A principal meta para o tratamento da luxação ou subluxação anteriores no atleta é o retorno às mesmas atividades do período pré-lesional, com confiança, livre de dor, e sem limitação funcional. Embora controverso, a imobilização por três semanas após o evento primário seguida por acompanhamento fisioterápico, incluindo analgesia, ganho de amplitude de movimento e reforço muscular permanece rotina nos principais serviços.

Diferente de indivíduos sedentários, o tratamento conservador da luxação anterior em atletas está relacionado a maus resultados ${ }^{(24)}$ A maioria necessitará de procedimentos cirúrgicos para retomarem suas atividades esportivas ${ }^{(2,24)}$.

Dentre as técnicas cirúrgicas abertas utilizadas, encontramse os procedimentos de Putti-Platte Magnusson-Stack que encurtam o músculo subescapular e o transferem lateralmente. Outro é a transferência do coracóide à glenóide anterior descrita por Latarjet ${ }^{(11)}$. Embora o ultimo procedimento ainda seja utilizado com bons resultados em trabalhadores, ambos estão relacionados a resultados incompatíveis com a completa reabi-
During the primary event, when the shoulder is subjected to maximal abduction, external rotation and extension, the rotator cuff is unable to keep the humeral head centered in the glenoid fossa and does not resist to external forces, being then shifted to the back of the glenoid. Most of times, it remains below the coracoid $^{(19)}$. Capsuloligament injuries, if present, will occur in the weakest point (fatigue point) located in the inferior capsule and in the glenoid labrum, thus characterizing the Bankart injury ${ }^{(7,16,24)}$.

Although it is very difficult to distinguish dislocation episodes as regards recurrence, as well as between traumatic and atraumatic instability, particularly in young athletes; the factors to be taken into account are the classical mechanism of the trauma and the presence of generalized ligament hyperlaxity ${ }^{(11)}$. It is known that the age factor and the intensity of the early trauma are closely related. According to McLaughlin and McLellan ${ }^{(12)}$, the probability of recurrence is approximately $90 \%$ for athletes under 20 years of age, $60 \%$ for those aged between 20 and 40 , and $10 \%$ in for those over 40 years of age. Berg e Ellison ${ }^{(3)}$ adds a third category where repetitive micro traumatisms are held responsible for cumulative injuries in the stabilizing soft tissues, generating the so-called overuse injuries and, later, instability. Such is the case with swimmers, gymnasts, throwers and other athletes who overload their upper limbs.

The so-called apprehension shoulder is related to the fear that the shoulder may dislocate due to small forced or involuntary movements. Functionally, it may be more limiting than instability itself ${ }^{(19)}$.

Subluxation is common among athletes with recurrent dislocation, its main clinical manifestation being the "dead arm syndrome" or "secondary impact syndrome" in which abduction and external rotation lead to an anterior subluxation generating acute pain and momentary loss of should er function and a sudden fall(8).

The main purpose in the treatment of anterior luxation or subluxation in athletes is the return to their same pre-injury activities with confidence, no pain and no limited functionality. Controversial as it may be, the three-week immobilization after the primary event, followed by therapeutic monitoring including analgesia, gain in the amplitude of movements, and muscular reinforcement remains the routine in the main services.

Unlike sedentary individuals, the conservative treatment of anterior dislocation in athletes is related to poor results ${ }^{(24)}$. Most athletes will require surgical procedures in order to return to their sports activities ${ }^{((2,24)}$.

Current open surgical techniques include the Putti-Platt procedure and the Magnusson-Stack procedure, which shorten the subscapular muscle and transfer it laterally. Another one is the coracoid transfer to the anterior glenoid as described by Bristow and Latarjet ${ }^{(11)}$. Although this last procedure is still successfully used in workers, both procedures are related to results that are incompatible with full rehabilitation and return to activities requiring direct action of the shoulder, such as swimming and throwing, due to the restriction in external rotation ${ }^{(6,11,24)}$.

More attention has been given recently to anatomic repairs that correct at the same time ligament laxity and glenohumeral ligament avulsions ${ }^{(11)}$. Such repairs include the Broca-PerthesBankart procedure that involves the repair of Barkart injuries ${ }^{(1)}$ and 
litação a atividades de solicitação direta do ombro, como, por exemplo, esportes de arremesso e natação devido a limitação da rotação externa ${ }^{(6,11,24)}$.

Recentemente, maior atenção tem sido dada a reparos anatômicos, corrigindo, ao mesmo tempo, frouxidão ligamentar e avulsões de ligamentos glenoumerais ${ }^{(11)}$ Dentre eles, o procedimento de Broca-Perthes-Bankart, no qual realiza-se o reparo da lesão de Bankart(1) tem ganho popularidade e tem sido reconhecida como o procedimento cirurgico de escolha ${ }^{(5,11,24)}$. Alguns autores ${ }^{(16,18,21)}$ propõem que, além do reparo capsular, a correção da frouxidão ligamentar também deve ser considerada. Outros $\mathrm{s}^{(18,22)}$, porém defendem a abordagem mais anatomica possível para a restauração normal da função do ombro. Correntemente, âncoras de sutura têm sido usadas por simplificarem o procedimento. Reparado o defeito e inserções musculares as fibras proprioceptivas mantém-se funcionais e a amplitude de movimento é rapidamente alcançada(14,22). Estudos a longo prazo trazem resultados encorajadores quanto à reabilitação esportiva(15,16) , sendo sua taxa de recorrência em torno de 3 a $5 \%(5,6,8,11,24)$.

O objetivo do presente estudo é avaliar os resultados da reinserção capsulo-labral associada à correção de eventual frouxidão capsular utilizando a tecnica cirúrgica aberta de Bankart, com auxilio de âncoras em atletas não profissionais, analisando resultados funcionais,e reabilitação esportiva comparativa ao período pré-lesional.

\section{CASUÍSTICA E MÉTODOS}

No período de Fevereiro de 1999 a Março de 2002, vinte e um atletas não profissionais (vinte e um ombros) foram submetidos ao tratamento cirúrgico da luxação recidivante no serviço de Ortopedia e Traumatologia do Hospital de Base de São J osé do Rio Preto. A idade variou de vinte e um a trinta e seis anos, com media de 26,63 anos. Dezenove pacientes $(90,47 \%)$ eram do sexo masculino e dois $(9,52 \%)$ do sexo feminino. 0 lado dominante foi o direito em dezessete indivíduos $(80,95 \%)$ e esquerdo em quatro (19,04\%). 0 lado direito foi afetado em quatorze pacientes $(66,66 \%)$ e o esquerdo em sete $(33,33 \%)$. 0 tempo médio entre a primeira luxação e a cirurgia foi de 26,63 meses, variando de três meses a nove anos. 0 intervalo médio entre os episódios de luxações foi de vinte e nove dias, variando de cento e oitenta a um dia (Tabela 1 ).

Todos os pacientes foram operados pela mesma equipe cirúrgica. 0 pós-operatorio variou de cinco a trinta e nove meses, com media de vinte e dois meses.

Quanto às modalidades esportivas, avaliou-se oito jogadores de futebol $(38,09 \%)$, quatro peões de rodeio $(19,04 \%)$, três praticantes de volleyball $(14,28 \%)$, um jogador de handball $(4,76 \%)$, um ciclista $(4,76 \%)$, um praticante de salto a distancia $(4,76 \%)$ e um nadador (4,76\%).0 numero de atletas no qual o uso do ombro estava diretamente relacionado à modalidade esportiva foi, portanto, de oito indivíduos (38,09\%), incluindo as modalidades volleyball, handball e rodeio.

Notou-se que, em doze pacientes $(57,14 \%)$, a luxação primária ocorreu durante a pratica esportiva e em nove $(42,85 \%)$ is increasingly employed and known as the surgical procedure of choic $\mathrm{e}^{(5,11,24)}$. Some authors ${ }^{(16,18,21)}$ proposed that, besides the capsule repair, the correction of ligament laxity should also be considered. However, other authors ${ }^{(18,22)}$, advocate the mostanatomical approach possible for the normal recovery of the shoulder function. Currently, suture anchors are employed because they simplify the procedure. Once the defect is repaired and muscle insertions are performed, the proprioceptive fibers will remain functional, and the amplitude of movement is rapid ly achie$\operatorname{ved}^{(14,22)}$. Long-range studies report encouraging results regarding sports rehabilitation ${ }^{(15,16)}$, with a recurrence rate of approximately 3 to $5 \%(5,6,8,11,24)$.

The purpose of the present study is to evaluate the results of capsulolabral reinsertion associated to correction of a possible capsule laxity by using the Bankart's open a surgical technique with the aid of anchors in nonprofessional athletes, and analyzing functional results and sports rehabilitation as compared to the pre-injury period.

\section{CASES AND METHODS}

From February 1999 to March 2002, twenty-one nonprofessional athletes (twenty-one shoulders) underwent surgical treatment for recurrent dislocation at the Orthopedics and Traumatology Unit of the Hospital de Base de Sao J ose do Rio Preto. The age group was 21 to 36 years, with a mean age of 26.63 years. Nineteen $(90.47 \%)$ were male patients and two $(9.52 \%)$ were female patients. The prevailing side was the right side in $17(80.95 \%)$ individuals, while the prevailing side was the left side in four (19.04\%) individuals. The right side was affected in $14(66.66 \%)$ patients, and the left side in seven (33.33\%). The average time between the first dislocation and the surgery was 26.63 months, ranging from three months to nine years. The average period between dislocation episodes was 29 days, ranging from 180 to 1 day (Table 1 ).

The same surgery team operated all patients. The postoperative period ranged from 5 to 39 months, with an average of 22 months.

As to the sports modalities, eight football players were evaluated $(38.09 \%)$, as well as four rodeo pawns (19.04\%), three volleyball players (14.28\%), one handball player (4.76\%), one cyclist $(4.76 \%)$, one distance jumper $(4.76 \%)$ and one swimmer $(4.76 \%)$. Thus, the number of athletes in which the use of the shoulder was related directly with the respective sports modality was eight (38.09\%), including volleyball, handball and rodeo.

It was noticed that in twelve $(57.14 \%)$ patients the primary dislocation occurred during the sports practice, while in nine $(42.85 \%)$ patients it was due to various traumas, including four occupational accidents due to falls, three motorcycle accidents, and two bicycle accidents.

All patients were attended at the emergency unit of Hospital de Base of Sao J ose do Rio Preto; 16 (76.19\%) patients were subjected to bloodless reduction and 4 , when assisted, had had their shoulders already reduced in a non-hospital environment; one $(4.76 \%)$ of them reported that the reduction spontaneously occurred at home and $3(14.28 \%)$ patients reported that their 
aconteceu devido a traumas diversos, dentre os quais, encontrou-se quatro acidentes de trabalho por queda de altura, três acidentes motociclísticos e dois acidentes ciclísticos .

Todos os pacientes foram atendidos na unidade de pronto atendimento do Hospital de Base de São J osé do Rio Preto, sendo dezesseis pacientes $(76,19 \%)$ submetidos à redução incruenta e quatro, quando atendidos, já haviam tido seus ombros reduzidos em ambiente não hospitalar, dentre os quais, um paciente $(4,76 \%)$ referiu ter conseguido a redução por si próprio em sua casa e três pacientes $(14,28 \%)$ referiram ter tido seus ombros reduzidos por leigos. Todos foram imobilizados por enfaixamento do membro superior pelo período de três semanas. 0 perío do subseqüente de seis semanas em média, variando de uma a oito semanas seguiuse por fisioterapia, incluindo movimentos pendulares, exercícios para ganho de amplitude de movimento e, por fim, exercícios para ganho de força muscular,sendo acompanhados ambulatorialmente pela equipe médica.

Quanto aos sintomas pré-operatórios, em dez pacientes $(47,61 \%)$, as queixas eram de instabilidade, descritas como "sensação de falseio", houve predomínio da dor às atividades diárias em três pacientes $(14,28 \%)$ e em cinco pacientes $(23,09 \%)$ houve somatória de ambas as queixas (Tabela 2 ).

Todos os pacientes foram submetidos ao exame físico ortopédico pré-operatório. Em nenhum caso notou-se hiperfrouxidão ligamentar generalizada ou volição à luxação. Durante o exame goniométrico, registrou-se abdução média de 96,34 graus, variando de sessenta a cento e vinte e cinco graus, enquanto a rotação externa média deu-se 22,8 graus, variando de dez a trinta graus e a média de rotação interna de $L 2$, variando de L1 a T12. 0 teste do sulco foi positivo em três pacientes $(14,28 \%)$ e negativo nos demais (Tabela 2 ).

Para melhor avaliar os resultados, foram utilizados os critérios de Rowe et al. ${ }^{(20)}$, que se basearam na estabilidade, função e amplitude de movimento. A reabilitação ao esporte, bem como fatores relacionados foram analisados separadamente. Considerou-se como resultados excelentes os pacientes sem recidiva da luxação, movimentos normais, sem limitações para o trabalho, grande satisfação subjetiva e confiança no ombro operado. Resultados considerados bons incluíram discreta apreensão, recuperação de, pelo menos, setenta e cinco por cento dos movimentos e discreta limitação ao trabalho. Resultados shoulders had been reduced by a layperson. All patients had their upper limbs immobilized with bandages for 3 weeks. The following period ranged from one to eight weeks, with an average of six weeks and was dedicated to physiotherapy including pendular movements, exercises to gain movement amplitude and, finally, exercises to gain muscle strength; the medical team monitored all patients ambulatorially.

As to preoperative symptoms, ten $(47.61 \%)$ patients complained of instability described as a "feeling of misstep"; pain prevailed in the day-to-day activities of 3 $(14.28 \%)$ patients, while 5 (23.09\%) patients reported both types of complaints (Table 2 ).

All patients were submitted to a preoperative orthopedic physical evaluation. In no case a generalized ligament hyperlaxity or volition to dislocation was observed. During the goniometric examination, a mean abduction of 96.34 degrees was recorded, in a range from 60 to 125 degrees, while the mean external rotation was of 22.8 degrees in a range from 10 to 30 degrees and the mean internal rotation was of $L 2$, varying from $L 1$ to $T 12$. The sulcus test (4) was positive in 3 $(14.28 \%)$ patients and negative in the others (Table 2).

In order to better evaluate our findings, we used the criteria of Rowe et $\mathrm{al}^{(20)}$, which are based in movement stability, function and amplitude. Sports rehabilitation and related factors were analyzed separately. Results were considered excellent if patients presented no dislocation recurrence, presented normal movements without work limitation, high subjective satisfaction and trust regarding the operated shoulder. Good results included discreet apprehension, recovery of at least $75 \%$ of movements and discreet work limitation. Regular results included subluxation, apprehension, reduction in the amplitude of movements, and work limitation. Poor results included recurrence of dislocation associated to apprehension.

The $X$-rays taken during the preoperative period showed that eight $(38.09 \%)$ patients had Hill-Sachs injuries and six $(28.57 \%)$ showed Barkart injuries, while two (9.52\%) had both types of injuries and three (14.28\%) were normal. 
regulares incluíam subluxação, apreensão, redução da amplitude de movimentos e limitações ao trabalho. A recidiva da luxação associada à apreensão marcou os resultados pobres.

As radiografias feitas no período pré-operatório, oito $(38,09 \%)$ apresentavam lesão de HillSachs, em seis $(28,57 \%)$ visibilizou-se a lesão de Bankart, em duas $(9,52 \%)$ notou-se ambas as lesões e três $(14,28 \%)$ estavam normais.

\section{TÉC NICA CIRÚRGICA}

Após bloqueio interescalenico seguido de anestesia endotraqueal, o paciente foi colocado em decúbito dorsal na posição de cadeira de praia com apoio para os membros superiores e coxim para a escapula.A seguir, foi feito 0 antibiótico endovenoso profilático cefazolina na dose de ataque de 1,0 g IV administrado posteriormente a cada oito horas pelo perío do de quarenta e oito horas pós-operatórias. 0 paciente foi então submetido a exame físico sob anestesia para que as direções da instabilidade fossem determinadas. Se o componente inferior estivesse presente pelo sinal do sulco positivo, indicou-se o retensionamento capsular.

Após antissepsia e a colocação de campos estéreis, realizou-se uma incisão na margem anterior axila que se estendeu até o coracóide e abertura entre o espaço delto-peitoral (Figura 1).

0 tendão conjunto foi afastado medialmente e o músculo subescapular, localizado e desinserido transversalmente $1,5 \mathrm{~cm}$ próximo à tuberosidade menor,tendo o cuidado para que a cápsula articular não fosse aberta neste tempo (Figura 2)

A seguir, o músculo foi reparado com fios de algodão e rebatido medialmente. A cápsula foi aberta em "T" até a borda da glenóide. Esta foi cruentizada para colocar as ancoras que fixaram o tendão do subescapular com fio inabsorvível ethbond ${ }^{\circledR}$ número 2 . 0 numero de ancoras utilizadas dependeu do tamanho da lesão de Bankart encontrada (Figura 3).

O nervo axilar, artéria e veia circunflexa do úmero eram sempre protegidos pelos afastadores. 0 tendão seccionad o foi reparado com fio inabsorvivel ethbond ${ }^{\circledR}$ numero 5 e a cápsula inspecionada, sendo feita sutura da fenda quando encontrada entre 0 ligamento superior e médio.

A seguir, prosseguiu-se o fechamento da cápsula. 0 retalho inferior foi primeiramente fechado e depois rodado o retalho superior no sentido inferior com a posição do membro rotação externa de 10 graus,

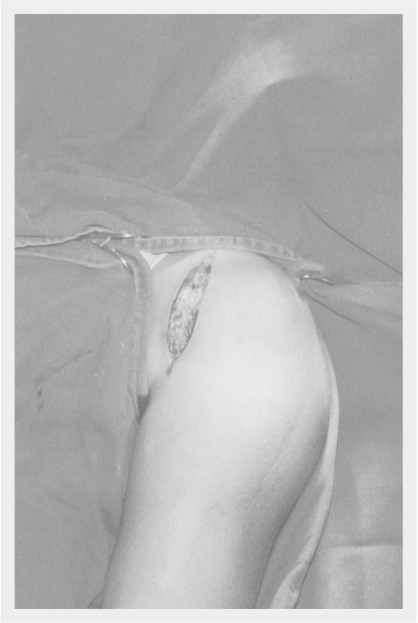

Figura 1 - Incisão anterior da prega axilar no processo coracóide. Figure $\mathbf{1}$ - Anterior incision from axillary fold toward the coracoid.

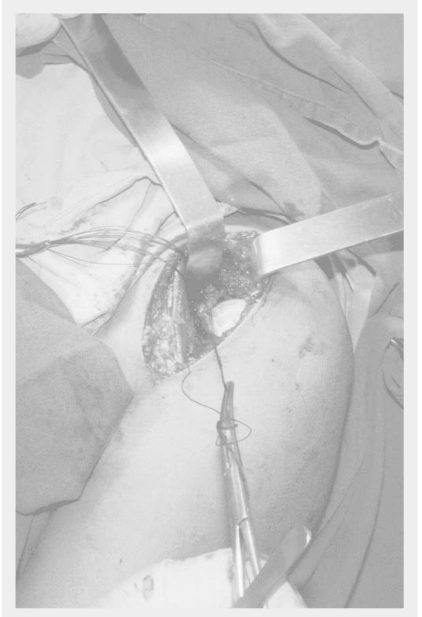

Figura 2 - Incisão do tendão subescapular, separado da cápsula por fios de algodão.

Figure $\mathbf{2}$ - Subescapularis tendon incision, separated from the capsule using cotton sutures.

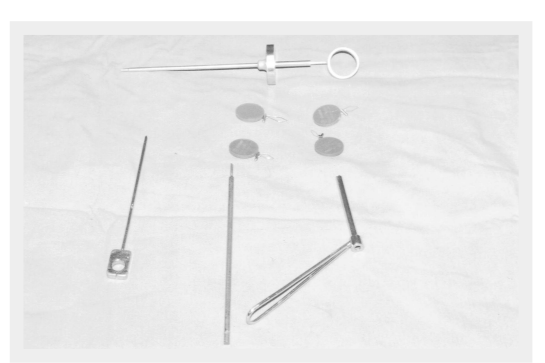

Figura 3 - Materiais utilizados para fixar âncoras no rebordo anterior da glenóide.

Figure 3 - Material used to fix the anchors at the anterior glenoid neck.

\section{SURGICAL TECHNIQUE}

After an interscalene block followed by endotracheal anesthesia, the patient was placed in dorsal decubitus position (as in a deckchair) with a support for both upper limbs and a pad for the scapula. A prophylactic intravenous antibiotic as a bolus of cephazoline 1.0 $\mathrm{g}$ i.v. was administered every 8 hours during the subsequent 48-hour postoperative period.

Then the patient was anesthetized and underwent physical examination in order to determine all directions of instability. In case the presence of the inferior component was shown by a positive sulcus signal, capsule retensioning was prescribed.

After antisepsis and after the placement of sterile fields, one incision was performed in the lower margin axilla, which was extended to the coracoid and the opening between the deltopectoral spac (Figure 1). The joint tendon was medially moved away and the subscapular muscle was located and transversally disinserted at a distance of $1.5 \mathrm{~cm}$ from the lesser tuberosity, taking care so that the joint capsule was not open in the process (Figure 2). Then the muscle was repaired with cotton thread and medially rebated. The capsule was opened up to the border of the glenoid in a T-shape. The latter was bloodied in order to place the anchors that fixed the subscapular tendon using nonabsorbentEthibond ${ }^{\circledR} \# 2$ thread. The number of anchors employed depended on the size of the Barkart injuries found. The axillary nerve, the artery, and the circumflex vein of the humerus were protected all the time by retractors (Figure3).

The sectioned tendon was repaired using nonabsorbent Ethibond ${ }^{\circledR}$ \#5 thread and the capsule was inspected; then, if an opening was found between the superior and medial ligament, it was sutured.

The closing of the capsule was then performed. The inferior remnant piece was initially closed; then, the superior remnant piece was rotated in the lower direction, with a 10-degree external rotation of the limb. A 20-degree abduction and a 90-degree bending of the elbow were maintained. In patients with sulcus sign present, the closing was performed with higher superior and lateral tensioning. The rotating interval was then closed using absorbable Vycril ${ }^{\circledR} \# 0$ thread, with separated, non-tensioned knots, so that external rotation was not impaired. Both the subscapular space and the delto- 
abdução de 20 graus e flexão de cotovelo em 90 graus. Nos pacientes cujo sinal do sulco estava presente, a o fechamento foi dado com maior tensionamento superior e lateral. 0 intervalo rotador foi então fechado por fio absorvível vycril ${ }^{\circledR}$ número 0 com pontos separados sem tensão para não prejudicar a rotação externa

O subescapular e espaço delto-peitoral foram suturados utilizando-se o mesmo fio e, posteriormente a pele com pontos subcutâneos contínuos com fio nylon ${ }^{\circledR}$ número 3.0 .0 paciente foi imobilizado com auxilio de tipóia fixa com coxim abdutor, e após, foram feitas radiografias de controle pós-operatorio ainda no centro cirúrgico (Figura 4)

\section{RESULTADOS}

Dos 21 pacientes operados, quinze $(71,42$ \%) foram classificados como excelentes, três $(14,28 \%)$ bons, dois regulares $(9,52 \%)$ e um $(4,76 \%)$ resultado ruim ( Tabela 3 ).

A apreensão permaneceu em quatro $(19,04 \%)$ pacientes, dor residual e instabilidade em quatro $(19,04 \%)$ e três $(14,28 \%)$ pacientes, respectivamente.A média obtida da rotação interna, utilizando a o nível vertebral atingido quando o paciente encostou o dorso da mão nas costas e externa foi de T12. As médias obtidas para rotação externa e abdução foram de 27,19 e 166,90 graus,respectivamente (Figura 5 ).

0 teste do sulco positivo em um $(4,76 \%)$ paciente e a recidiva, presente em dois $(9,52 \%)$. De todos os pacientes operados, apenas um não retornou ao trabalho.0 mesmo apresentou perda da amplitude de movimento e apresentava-se com queixas de dor e apreensão. Associouse este mal resultado ao abandono precoce das atividades fisioterápicas de reabilitação e tentativa frustra de retomo a atividades esportivas.

0 retorno a atividades esportivas deuse em 16 atletas (76,19\%). Destes, apenas dez retornam às atividades do período pré - lesional na mesma intensidade. Os seis restantes que referiram ter retornado de maneira parcial ao esporte apontaram o medo de uma nova luxação como causa da não reabilitação por completa. Dos sete pacientes que referiram abandono das atividades físicas, dois $(9,52 \%)$ relataram dor residual, um $(4,76 \%)$ dor as-

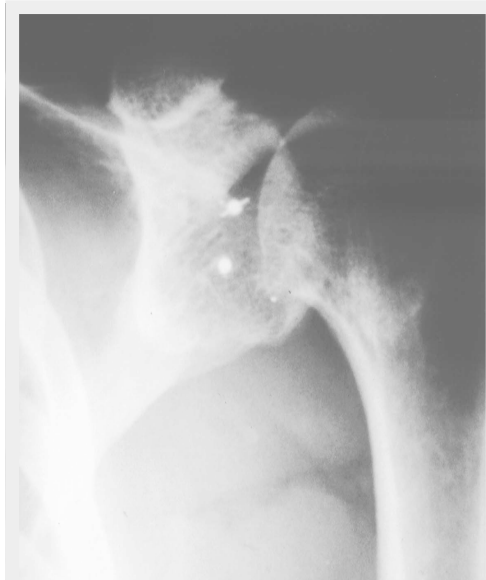

pectoral space were sutured using the same thread; the skin was then sutured with continuous subcutaneous knots using Nylon ${ }^{\circledR} \# 3.0$ thread.

The patient was immobilized with the aid of a fixed sling with abduction pad; then, postoperative control $\mathrm{X}$-rays were performed still in the surgical center (Figure 4).

\section{RESULTS}

Of the 21 operated patients, fifteen $(71.42 \%)$ were graded with excellent results, three $(14.28 \%)$ with good results, two $(9.52 \%)$ with regular results and one $(4.76 \%)$ with poor result (Table 3).

Apprehension remained in four (19.04\%) patients, and residual pain and instability in four (19.04\%) and three (14.28\%) patients, respectively. The mean internal and external rotation values were T12 and 27.19 degrees, respectively. Mean abduction was 166.90 degrees; the sulcus test was positive in one $(4.76 \%)$ patient, while two $(9.52 \%)$ experienced recurrences. Of all operated patients, only one did not return to work. This patient had a loss in the amplitude of movements and complained of pain and apprehension. This poor result was associated to the early withdrawal of physiotherapeutic rehabilitation activities and the frustrated attempt to return to sports activities (Figure 5).

Sixteen $(76.19 \%)$ athletes returned to their sports activities. Of the 16 , only ten returned to the pre-injury period activities at the same intensity. The six remaining patients who reported having returned in part to sports said that fear of a new dislocation was the cause of their noncomplete rehabilitation. Of the seven patients who reported having abandoned their physical activities, two $(9.52 \%)$ reported residual pain, one $(4.76 \%)$ reported pain associated to a feeling of instability, and four (19.04\%) reported fear of new injuries

No postoperative complications were found, such as skin necrosis, suture dehiscence, or infection in the surgical wound.
Figura 5 - Exame físico após oito semanas do período pós-operatório, mostrando rotação interna e adução atingidos.

Figure $\mathbf{5}$ - Physical examn after eight postoperative weeks showing internal rotation and aduction. 
sociada a sensação de instabilidade e quatro $(19,04 \%)$ devido por medo de novas lesões.

Não se constatou complicações pós-operatórias como necrose de pele, deiscência de sutura e infecção da ferida cirúrgica.

\section{DISCUSSÃO}

A luxação glenoumeral traumática é uma lesão freqüente. Esportes de contato e arremesso, populares na américa do norte apresentam maiores taxas desta lesão. Sua gênese está relacionada tanto ao trauma violento gerado durante o esporte, quanto por microtraumas repetitivos (overuse) ${ }^{(4,15,16)}$. Bigliani et al. ${ }^{(5)}$ relataram que a maior parte das lesões davam-se principalmente no Baseball $(23,5 \%)$, Tênis (22\%) e futebol americano $(17,64 \%)$. Uhorchak et al. ${ }^{(24)}$ encontraram taxas da lesão em $84,12 \%$ dos jogadores de futebol americano e em $20 \%$ dos praticantes de esporte de contato limitado (incluindo volleyball e handball). No presente estudo notou-se predominância da lesão no futebol $(38,09 \%)$, certamente por sua grande popularidade no país, seguido pelo Rodeio(19,04\%), prática na qual o atleta ao manter um dos ombros abduzido e rodado externamente, é submetido a forças multidirecionais de forte intensidade que podem levar à luxação primária.A terceira maior taxa foi apresentada em praticantes de volleyball $(14,28 \%)$, devido, talvez à grande energia cinética ao qual submete a articulação glenoumeral.

A instabilidade desenvolvida após a lesão inicial está relacioanda à idade ${ }^{(8,9,19)}$ e pode apresentar-se clinicamente não só por episódios de recorrência, mas também por dor mal caracterizada, muitas vezes confundida com a Síndrome do impacto. Nicoletti et al. ${ }^{(15)}$, notaram que nos pacientes com menos de quarenta anos $(44,42 \%)$ havia algum grau de instabilidade e salientou a associação de dor e instabilidade em $28,57 \%$ dos pacientes e instabilidade de maneira isolada em $47,61 \%$.

A instabilidade traumática anterior tratada de maneira consenvadora está relacionada a sucesso limitado e o tratamento cirúrgico é freqüentemente necessário ${ }^{(8,24)}$. Cirurgias que encurtam o musculo subescapular, ou que o transferem lateralmente estão associadas à perda da rotação externa, muitas vezes incompatível com a reabilitação ao esporte ${ }^{(11,23,25)}$. A cirurgia aberta com 0 reparo de Bankart está relacionada bons resultados e taxas de recorrência de 3 a $5 \%$ na população gera||(5,6,8,11,24). Alguns estudos apontam taxas ainda maiores em atletas, certamente pela maior solicitação mecânica a que a capsula e ligamentos são envolvidos ${ }^{(7,11)}$. Paim et al. ${ }^{(16)}$ relataram que a tecnica Bankart modificada por Matsen apresentou $77 \%$ de resultados excelentes, $18 \%$ de bons, $5 \%$ de regulares, sem nenhum caso de recidiva. Schott et al. ${ }^{(21)}$ encontraram $100 \%$ de retorno ao trabalho e nenhum caso de recidiva em vinte ombros operados ${ }^{(3)}$. J obe atal.(10), em obtiveram $92 \%$ de resultados excelentes e bons, sem nenhum relato de instabilidade pós-operatória em atletas. Bigliani et al. ${ }^{(4)}$ obtiveram $67 \%$ de excelentes resultados, $27 \%$ de bons resultados, e $6 \%$ de resultados ruins. Uhorchak et al. ${ }^{(24)}$ estudando atletas encontrou $75 \%$ de excelentes e bons resultados, porém com taxa de instabilidade pós-operatória de $22,72 \%$, incluindo luxações e subluxações e a atribui a esportes de colisão e contato. Veado et al. ${ }^{(25)}$, em 1997, encontrou $91,5 \%$ de resultados bons e excelentes , $4,2 \%$ de regulares e $4,2 \%$ de ruins Nesta casuística, $71,42 \%$ dos ombros operados foram classificados como exce-

\section{DISCUSSION}

Traumatic glenohumeral dislocation is a frequent injury. Contact sports and throwing, so popular in North America, show the highest rates of this type of injury. Its genesis is related both to the violent trauma generated during the practice of sports and to repeated microtraumas (overuse) $)^{(4,15,16)}$. Bigliani et al(5) reported in 1994 that most injuries occurred mainly during baseball games (23.5\%), tennis games (22\%) and football (17.64\%). In 2000 Uhorchak et $\mathrm{al}^{(24)}$ found the following injury rates: in $84.12 \%$ for football players and in $20 \%$ for people practicing any limited contact sport (including volleyball and handball). In the present study, football injuries prevailed (38.09\%), certainly due to its popularity in the USA, followed by the rodeo (19.04\%), a practice where the athlete's shoulder must be maintained abducted and externally rotated while subjected to high-intensity multidirectional forces that may lead to primary dislocation. The third largest rate relates to volleyball players $(14.28 \%)$ probably due to the fact that the glenohumeral joint is subjected to large amounts of kinetic energy.

The instability developed after the early injury is related to age ${ }^{(8,9,19)}$ and may present clinic ally not only by recurrence ep isodes, but also by pain that is not well characterized and is confused with the impact syndrome. Nicoletti et al ${ }^{(15)}$ in 1996 noticed that patients under 40 years of age $(44.42 \%)$ showed a certain instability level and emphasized the association between pain and instability in $28.57 \%$ of the patients, and isolated instability in $47.61 \%$.

When conservatively managed, anterior traumatic instability relates to a limited success, surgical treatment being often requi$\operatorname{red}^{(8,24)}$. Surgeries that shorten the subscapular muscle or transfer it laterally are associated to external rotation loss, frequently incompatible with sports rehabilitation ${ }^{(11,23,25)}$. Open surgery with Bankart's repair relates to good results and recurrence rates of 3 to $5 \%$ in the population in general ${ }^{(5,6,8,11,24)}$. Some studies show even higher rates in athletes, certainly due to the fact that the capsule and the ligaments are more requested mechanic ally ${ }^{(7,11)}$. In 1995 Paim et al(16) reported that the Bankart Technique modified by Matsen provided $77 \%$ excellent results, $18 \%$ good results, $5 \%$ regular, and no cases of recurrence. In 1994 Schott et al (21) found $100 \%$ of return to work and no case of recurrence in twenty operated shoulders ${ }^{(3)}$. In 1991 J obe at al ${ }^{(10)}$ obtained $92 \%$ excellent and good results and no reports of postoperative instability in athletes. In 1994 Bigliani et al(4) had $67 \%$ excellent results, $27 \%$ good, and $6 \%$ poor. In 2000 , Uhorchak et al ${ }^{(24)}$, in a study in athletes, found $75 \%$ excellent and good results, although the postoperative instability rate was $22.72 \%$, including luxations and subluxations; the authors relate this rate to collision and contact sports. In 1997 Veado et al ${ }^{(25)}$ found $91.5 \%$ of good and excellent results, $4.2 \%$ regular and $4.2 \%$ poor results. In this group of cases, $71.42 \%$ of the operated shoulders were graded as excellent, $14.28 \%$ as good, $9.52 \%$ as regular, and $4.76 \%$ as poor results. Instability remained in $19.04 \%$ of patients and the rate of return to work was $95.26 \%$.

The return to sports, with or without the previous competitiveness levels, involves more complex factors such as the severity of the trauma, previous injuries, postoperative complications, sports modality, physiotherapeutic monitoring, and motivation. 
lentes, $14,28 \%$ bons, $9,52 \%$ regulares e $4,76 \%$ de resultados pobres. A instabilidade permaneceu em $19,04 \%$ dos pacientes e a taxa de retomo ao trabalho foi de $95,26 \%$.

0 retorno ao esporte acompanhado ou não dos níveis anteriores de competitividade envolve fatores mais complexos, incluindo a gravidade do trauma, lesões prévias, complicações pósoperatórias, modalidade esportiva, acompanhamento fisioterápico e motivação. J obe e Kvitne ${ }^{(10)}$ encontraram $100 \%$ de retorno ao esporte, mas com reabilitação completa em $72 \%$ dos pacientes. Bigliani et al. ${ }^{(4)}$ relatam retomo aos esportes em $92 \%$ dos pacientes, porém com apenas $75 \%$ de reabilitação plena, retornando aos mesmos níveis de desempenho anteriores, notando maior dificuldade reabilitativa nos praticantes de esportes de arremesso. Veado et al. ${ }^{(25)}$ notaram recuperação inadequada ao esporte devido à apreensão e a atribuiu a falta de exercícios de coordenação muscular e propriocepção. 0 presente estudo apresentou dados semelhantes. 0 retorno a atividades esportivas deuse em 16 atletas (76,19\%), dos quais dez apresentaram reabilitação plena. As principais causas responsáveis pelo abandono e o retorno parcial ao esporte foram o medo de uma nova luxação, seguido pela dor e instabilidade. A apreensão mantida em ombros estáveis e indolores traduz aspectos psicológicos a serem trabalhados e certamente estarão presentes nos futuros protocolos de reabilitação esportiva.

\section{CONCLUSÃO}

O procedimento de Bankart com âncoras mostrou-se eficaz no tratamento da instabilidade traumática anterior do ombro de atletas não profissionais, podendo ser realizado de maneira isolada, ou associado ao retensionamento capsulo-ligamentar.

\section{REFERÊNCIAS BIBLIOGRÁFICAS}

1 - Altcheck DW, Warren RF. T- plasty modification of the Bankart procedure for multidirectional instability of the anterior and inferior types. J Bone J oint Surg Am 73:105-112, 1991.

2 - Aronen J G, Regan K. Decreasing the incidence of recurrence of first time anterior shoulder dislocations with rehabilitation. Am J Sports Med 12:283-291, 1984.

3 - Berg EE, Ellison AE. The inside-out Bankart procedure. Am J Sports Med 18: 129-133, 1990.

4 - Bigliani LU, Kurzweil MD, Schwartzbach CC et al. Inferior capsular shift procedure for anterior-inferior shoulder instability in athletes. Am J Sports Med 22:578 $584,1994$.

5 - Checcia SL, Doneux PS. Tratamento cirúrgico da luxação recidivante anterior do ombro pela técnica da capsuloplastia associada com reparação da lesão de Bankart. Rev Bras Ortop 28:609-616, 1993.

6 - Collins HR, Wilde AH. Shoulder instability in athletics. Orthop Clin North Am 4:759-774, 1973.

7 - Craythorne CB, Glasgow MT. A long term evaluation of the modified Bristow procedure for anterior glenohumeral instability. Orthop Trans 17:973-974, 1994.

8 - Ferreira Neto AA. Instabilidade anterior do ombro. In: Pardini AG. Clinica Ortopédica. Atualização em cirurgia do ombro. Rio de J aneiro: Medsi, 2000. p.155-164.

9 - Iannoti J P, Willians GR. Anterior and anteroinferior instability: diagnosis and management disorders of the shoulder. Philadelphia:Willians \& Wilkins, 1999. p.251292

10 - J obe FW, Kvitne RS. The diagnosis and treatment of anterior instability in the throwing athlete. Clin Orthop 291:23-107, 1993.

11 - Latarjet M. A propos du traitment des luxations récidivantes de I'epaule. Lyon Chir 49:994-998, 1954.

12 - McLaughlin HL, McLellan DI. Recurrent anterior dislocation of the shoulder: A comparative study. J Trauma 7:191-201, 1967.

13 - Miller LS, Donahue J R. The magnun-stack procedure for treatment of recurrent glenohumeral dislocations. Am J Sports Med 12:133-137, 1984.
J obe and Kivtne ${ }^{(10)}$ found a $100 \%$ rate in return to sports, but with complete rehabilitation in $72 \%$ of the patients. Bigliani et al(4) report a return to sports in $92 \%$ of the patients, although they found only $75 \%$ full rehabilitation, returning to the same performance levels as before, and observing more difficulty in the rehabilitation of throwers. Veado ${ }^{(25)}$ noticed inappropriate recovery to sports due to apprehension, and related it to lack of muscle coordination exercises and proprioception. The present study showed similar data. Sixteen athletes returned to sports activities (76.19\%), with 10 of them presenting full rehabilitation. The main causes of abandonment and partial return to sports were fear of a new dislocation, followed by pain e instability. The apprehension maintained in painless, stable shoulders translates psychological aspects to be developed, and most certainly will be present in future sports rehabilitation protocols.

\section{CONCLUSION}

The Bankart procedure with anchors has shown to be effective in the treatment of anterior traumatic instability of the shoulder in nonprofessional athletes and can be performed either alone or associated with capsuloligament retensioning.
14 - Myers J B, Lephard SM. Sensimotor déficits contributing to glenoumeral instability. Clin Orthop 400:98-104, 2002.

15 - Nicoletti S, Carrera EF, Ejnisman B et al. Tratamento cirúrgico da instabilidade glenohumeral pela técnica de Bankart e capsuloplastia de Neer: Avaliação de resultados e descrição de complicações incomuns. Rev Bras Ortop 33:700-704, 1998. 16 - Paim AE, Miranda AR, Massote RM, Carlos RF. Técnica de Bankart modificada por Matsen para o tratamento das instabilidades traumáticas do ombro : capsulorrafia sem capsuloplastia. Rev Bras Ortop 30:687-692, 1995.

17 - Paulos LE, Evans LK. Anterior and anterior-inferior shoulder instability : Treatment by glenoid labrum reconstruction and a modified capsular shift procedure. J Shoulder Elbow Surg 2:305-313, 1993.

18 - Raymundo J LP, Lange C. Pregueamneto ou capsulorrafia ? Nota preliminar. Rev Bras Ortop 31:742-744, 1996.

19 - Rockwood CA, Thomas SC, Matsen FA. Subluxações e luxações da articulação glenoumral.In: Rockwood CA ,Green DP, Bucholz RW, Fraturas em adultos. $3^{\text {rd }}$ ed. São Paulo:Manole, 1999. p.1003-1156.

20 - Rowe CR, Patel D, Southmayd WW. The Bankart procedure. A long-term endresult study. J Bone J oint Surg Am 60:1-16, 1978.

21 - Schott PCM, Watzl MTP. Tratamento cirúrgico da luxação recidivante do ombro. Modificação da técnica de Bankart. Rev Bras Ortop 29:337-340, 1994.

22 - Steven CT, Matsen FA. An approach to the repair of avulsion fo glenoumeral ligaments in management of traumatic anterior glenoumeral instability. J Bone J oint Surg 71:506-513, 1989.

23 - Torg J S, Balduini FC. A modified Bristow-Helfet-May procedure for recurrent dislocation and subluxation of the shoulder. Report of two hundred and twelve cases. J Bone J oint Surg Am 69:904-913, 1987.

24 - Uhorchak J M, Arciero RA, Huggard D, Taylor TC. Recurrent shoulder instability after open reconstruction in athletes involved in collision and contact sports. Am J Sports Med 28:794-799, 2000.

25 - Veado MAC, Silva ED, Mieira MG. Tratamento cirúrgico da instabilidade anterior recidivante do ombro com reparo da lesão de Bankart e/ou tensionamento capsular. Rev Bras Ortop 32:741-745, 1997. 
O arquivo disponível sofreu correções conforme ERRATA publicada no Volume 11 Número 4 da revista. 